VS Publications

Alford Council of International English \& Literature Journal(ACIELJ)

Impact Factor:4.401(SJIF)An International Peer-Reviewed English Journal

www.acielj.com

Vol-3,Issue-2, 2020

ISSN:2581-6500

\title{
THE INTERFACE BETWEEN LANGUAGE AND LITERATURE: DESIGNING AN INTEGRATED MODEL
}

\author{
Md SIkandar Ali \\ Associate Professor \\ Department of English \\ Shahjalal University of Science and Technology, Bangladesh
}

\begin{abstract}
Teaching language through literature is not anything new. But the "Integrated Model" was first coined by Duff and Maley(1990). As there is no clear and concrete frame work of an 'Integrated Model' before us so far, it still remains a matter of speculation. The fundamental difference between the 'integrated model' and 'language through literature' is that the former pays attention to both language and meaning while the latter is concerned with language alone. Besides boosting language proficiency, an 'integrated model', as it is conceived, would encourage reflective learning, engage learners in problem solving, initiate them into participatory and cooperative learning, train them to relate the text to life experience as suggested in post-method pedagogy. An equally important goal is to develop students' logical thinking as well as critical and analytical abilities. This paper proposes to explore how best language can be taught by adopting the 'Integrated Model'.
\end{abstract}

Keywords: Interface, language, literature, integrated model

\section{Literature Review}

Language and literature are inherently related. Literature exists in language and its content gets communicated through language. "A literary text is authentic text, real language in context to which one can respond directly" (Brumfit and Carter, p. 15). But language not only conveys message of the content but also signifies meaning of symbols which convey more than literal meaning of the words. This feature of language facilitates multiple interpretations of a literary text. A creative writer uses these tools- symbols, metaphors etc. to express oneself in special and unusual ways. Duff and Maley (1990) point out that literary texts are authentic and therefore "offer genuine samples of a very wide range of styles, registers and text-types at many levels of difficulty" ( $p$. 3 ). In addition to it, language of literary texts puts forth many genuine features of language like: vocabulary, word forms, structures, conventions, figures of speech and different uses of language.

The power of literary texts is underscored by Gilory and Parkinson (1996) as "authentic material which does not become stale" (p.215). It is very much evident that literature provides EFL/ESL learners with opportunity to explore language in its multiple varieties. For example drama may give an idea of how dialogue, speech and conversation work to attain the desired effect. Prose shows how language flows naturally and gives expression to human thoughts, feelings 
VS Publications

Alford Council of International English \& Literature Journal(ACIELJ)

Impact Factor:4.401(SJIF)An International Peer-Reviewed English Journal

www.acielj.com

Vol-3,Issue-2, 2020

ISSN:2581-6500

and emotion. Songs and poetry convey

melody of sounds of the language and use decorative language. In short, English literature being a most fascinating subject, can provide a platform to engage learners in fruitful language learning.

According to Richards (2005) materials must necessarily be motivational. Materials should generate and maintain interest, promote fun in learning and provide opportunities for students to speak about themselves. Literature exposes students to complex themes and fresh and unexpected usage of language. Stories and novels sustain students' interest through their gripping plots. For example when we read Oedipus Rex by Sophocles, we come across a story unmatched in the entire range eastern or western literature and cannot stop until we have finished reading. This involvement is more absorbing and enduring than that afforded by the narratives in newspaper reports.

Kramsch (1998) puts forward the opinion that literature promotes multicultural understanding leading to socio-linguistic, pragmatic and intercultural competence.Maley (1993) thus emphasizes: " Cultural awarenessraising is an aspect of values education.For example, Somerset Maugham's "Luncheon" gives us a peep into the European mind and society. In other words, literary texts have considerable potentials in language learning and appreciating a foreign culture (Fenner 2000, p. 146).

Literature helps expanding students' language awareness, (Lazar 1993). A literary text is different from other forms of discourse. It breaks the usual rules of syntax, collocation and even cohesion. This is more frequently the case in poetry. For instance, Though wedded we have been / These twice ten tedious years ("The Diverting History of John Gilpin Shewing how he went Farther than he intended, and came safe Home again "(6-7) by William Cowper). Here the prose form of the two lines will be 'Though we have been married for these twenty tedious years.' But the poet has expressed the same message in a different structure. We may wonder why we should expose students to such 'wrong' use of language. But these are not wrong uses as such but deviant uses. Cruz (2010) maintains that a literary text provides students with a clearer idea about structures of a written text and sensitizes them about how written text is different from the spoken tongue. (p.4)

One important aspect of studying literature is developing students' interpretative abilities (Lazar 1999).This is because literary texts are often rich with multiple levels of meaning. A word in a poem may have a powerful figurative meaning beyond its fixed dictionary meaning or a poem may have two layers of meaning- one literal and another metaphoric. Robert Frost's "Road Not Taken" is such an example. Again, when Robert Frost says: "But I have miles to go before I sleep" it may literally mean that he has to cover a long distance before taking rest. But it may also have a metaphoric meaning which implies that he has a myriad of duties to perform before his life comes to an end.

There are some devices that make a text beautiful and aesthetically pleasing. These are known as rhetorical devices. These include metaphor, simile, rhyme, 
VS Publications

Alford Council of International English \& Literature Journal(ACIELJ)

Impact Factor:4.401(SJIF)An International Peer-Reviewed English Journal

www.acielj.com

Vol-3,Issue-2 ,2020

ISSN:2581-6500

and rhythm. Gillian Lazar (1993) calls

them meta-language. Some other items under this category include paradox, oxymoron, metonymy, synecdoche, apostrophe, alliteration, assonance and so on (p. 44). Consider for example, when Robert Burns Says: "My luv's like a red, red rose" instead of "My beloved is beautiful'. Which expression will be more pleasing to his beloved? The first or the second one?

Certainly, the first, because he associates so many attributes to her. Instead of saying "my beloved" he says "My luv". Instead of just saying that she is beautiful, he compares her with a red rose which is beautiful, tender and full of fragrance. Being a Scotsman, he uses the spelling "luv" and not "love" which indicates the way the word is pronounced in his dialect and that makes the relationship more intimate. Also notice the alliteration 'luv'...like red, red rose. Ghosn(2002) says that literature is the manifestation of language in its finest form and thus fosters vocabulary development in context. Similar view is echoed by Widdowson (1975) as he says the study of literature is fundamentally a study of language in operation. Here we see that poems exhibit elegance of language.

Choice of words or diction is another important aspect one should try to explore in literature. J. Povey (1979) observes that "Literature will extend linguistic knowledge by giving evidence of extensive and subtle vocabulary uses and complex and exact syntax" (p.90). Choice of words determines the meaning. Particularly words carry various meanings in poetic lines. To quote from Brown: It saves a model. So! Keep looking so-/My serpentining beauty, rounds on rounds! (Andrea Del Sarto, 25-26). Browning uses the phrase 'serpentining beauty' in "Andrea Del Sarto" which is powerfully suggestive. On the surface level, it refers to the physical charm but the suggestion of a snake indicates that this beauty is not without its venom. In Browning's poem 'My last Duchess' the word moon carries a powerful metaphoric meaning: "My face, my moon and my everybody's moon." the implication of which is that the Duchess is equally generous to the duke as much as she is to a common man and her putting him on the same footing is clearly repugnant to the Duke.

Maley (1989) argues for literature in language classroom for its economy and suggestive power. Literature does not say everything explicitly. It has implicit messages that have to be decoded. It may use a few words but they can mean a lot. Literature has suggestive power and one has to read between lines. For instance when Mathew Arnold says: 'The sea is calm tonight' in his poem "The Dover Beach", it may mean there are no tides and that here is peace all around. It also means it is a suitable time to enjoy charms of life.

Critical thinking is accorded utmost importance in educational settings all over the world as it is the cornerstone of education, especially at advanced level. The language of literary texts is representational, which enables readers to re-create the experiences by using their imagination and creativity (Widdowson 1983). Apart from cultural and linguistic elements, literature can also stimulate the 
VS Publications

Alford Council of International English \& Literature Journal(ACIELJ)

Impact Factor:4.401(SJIF)An International Peer-Reviewed English Journal

www.acielj.com

Vol-3,Issue-2 ,2020

ISSN:2581-6500

imagination of students to develop their critical abilities and increase their emotional awareness (Ghosn, 2002).

\section{Kind of materials to be used}

Now the question pertinently arises: What kind of material is suitable for language teaching? The answer is any good piece of literature ( poem, story, anecdotes, travelogue etc.) is fit for language teaching. But precisely speaking an ideal text would be a text which a) engages affectively, b) challenges cognitively, c) promote language awareness and d) help learners to reflect critically about and respond imaginatively to the world where they live" ( Lima 2010). The inclusion of short fiction in ESL/EFL curriculum offers the following educational benefits (Violetta-Irene, 2015, p.76)

--Makes students' reading task easier due to being simple and short when compared with other literary genres.

-- Provides more creative, encrypted, challenging texts that require personal exploration supported with prior knowledge for advanced level readers.

-- Motivates learners to read due to being an authentic material

-- Gives students the chance to use their creativity

-- Promotes critical thinking skill

-- Facilitates teaching of foreign culture

--Makes students comfortable and free

-- Helps students to go beyond the surface meaning and dive into underlying meanings
Indisputably, stories and storytelling are an important part of language teaching since they are so pervasive in every aspect of our lives (Tatsuki, 2009). The text which has been selected here to work with is O' Henry's "The Gift of the Magi" suitable for higher secondary or first year undergrad level students. It is a story of a couple who sacrifice their most precious gifts for each other. The story has something of universality about it. It is appropriate for this age group who are likely to enjoy it.

\section{Different Approaches of Teaching L2}

Carter and Long (1991) describe three main approaches to teaching literature: The Cultural Model; the Language-based model; and the Personal Growth Model.

Cultural Approach employs

traditional approach to teaching literature. This model encourages exposure of foreign language learners to different cultures to understand and appreciate cultures and ideologies different from their own in time and space.

Language-based Approach pays attention to the way language is used. This approach is meant to increase general awareness of language. It focuses on specific features of language such as general grammar, vocabulary and use of stylistic analysis by creating tasks leading to multiple language activities. By using a wide range of authentic texts instructors can introduce learners to a variety of types and difficulties in the English language.

Personal Growth Approach stresses The personal enjoyment and emotional gain students can procure by engaging with such text (Maley, 2001). This model attempts to encourage students' interaction 
VS Publications

Alford Council of International English \& Literature Journal(ACIELJ)

Impact Factor:4.401(SJIF)An International Peer-Reviewed English Journal

www.acielj.com

Vol-3,Issue-2, 2020

ISSN:2581-6500

with the text. It encourages learners to draw on their opinions, feelings and personal experiences. Texts are seen as sources of linguistic development as well as literary appreciation. Literary discourse sensitizes readers to the process of reading that is the use of schemata, strategies for intensive and extensive reading etc. This model recognizes the immense power to move readers.

\section{Integrated model}

'Integrated Model' convincingly combines elements from three models in existence in order to provide a more suitable approach. Integrated approach attempts to overcome the limitations and criticisms associated with the previous models and provides more reliable approaches to teaching literature in the modern EFL setting (Healy 2010, 179). It has also been suggested by Savvidou (2004) that a literary text should be approached in three different ways: firstly, as a cultural object; secondly, as a source of linguistic analysis; and thirdly, as a method for personal growth. She considers integrated approach as a "potentially powerful pedagogic tool" and sets out a six-stage scheme.

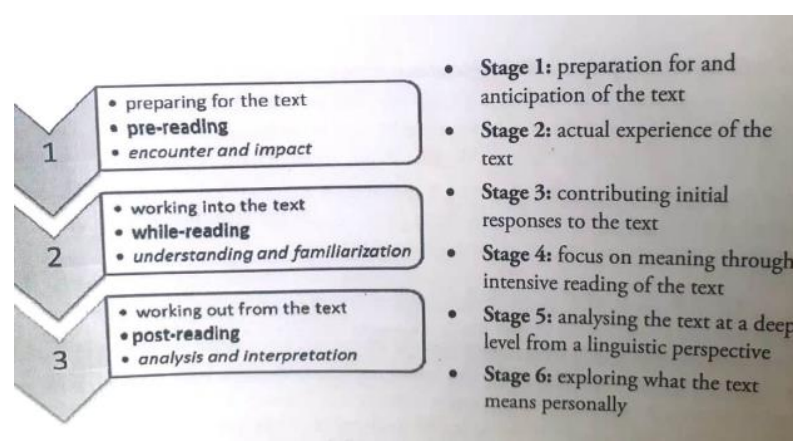

Savvidou's six-stage scheme

Tasks and activities on "The Gift of the Magi"
Taking Savvidou's proposed framework as a guide the following 'Integrated model' has been constructed.

\section{Pre-Reading Activities}

These activities are intended as warmer or icebreaker. Warmer induces students to guess, speculate and talk about the topic they are going to deal with in the class. This could be done in several forms: a short discussion that students do in pairs or it may be a whole class discussion. The course teacher can ask some questions and put students to brainstorming about what the topic might be about. The teacher may provide some hints or background information to facilitate the discussion. Khatib et al. (2011) propose the following lesson scheme for schema building for the pre-task phase:

\section{A. Brainstorming}

i) Contextualization of the task ( through pictures, realia, questions and answers)

ii) Illustration of the context

iii) Introduction of some of the key vocabulary items ( through matching, predicting, and guessing

B. Group scaffolding

C. Performing a similar task chorally

Here are some discussion questions which can be used as warmer.

- What do you think the title of the story will be about?

- Have you ever heard the word Magi? What does the Magi stand for?

- What kinds of gifts, if any, do you exchange on religious occasions? 
VS Publications

Alford Council of International English \& Literature Journal(ACIELJ)

Impact Factor:4.401(SJIF)An International Peer-Reviewed English Journal

www.acielj.com

Vol-3,Issue-2,2020

ISSN:2581-6500

- Talk about the most beautiful gift you have ever got.

\section{While-Reading Activities}

These activities are intended to help students to -

-- understand the plot, and

characters

-- increase the analytical and interpretative ability

-- acquire vocabulary and nuances

of meaning

-- pick up style and language

Taking all these aspects into consideration some tasks such as gap filling, problem solving and role playing can be developed to engage students in a variety of activities including discussion and writing (Maley2001, 183).

\section{Section A: Initial response}

- Why is buying the right gift for Jim important to Della?

- Why does Della count the amount of money three times?

- What makes Della flop down on the couch and howl? Do you think Della is being hyperactive?

Section B: Focusing on meaning through intensive reading and fostering critical thinking

- How do their financial circumstances contribute to the development of the plot?

- How does the last sentence of paragraph 2 help establish theme of the story?
- Why is the use of income discussed in terms of the use of full name or initial?

- How does the repetition of the word 'grey' convey the mood of Della?

- How does the story generate tension and overlap between commerce and religion?

\section{Section C: Helping with language \\ Helping with vocabulary}

\section{Task :1}

1. 'Close dealing' means-

a) bitter argument b) hard bargaining c) criticizing $d$ ) being friendly

2. 'Twenty dollars doesn't go far'. Here 'not go far' means-

a) inadequate b) go a short distance c) difficult to earn d) make little effort

3. It did not exactly 'beggar description'. Here the phrase means-

a) story about a beggar b) poor description c) Too bad to describe d) boring description

Task: 2

While reading underline the unknown words and guess the meaning from the context. 


\section{Task: 3}

Teaching vocabulary in context

Fill in each blank space in the following passagdistridss.words from the boxes. There are more words than you need.

It was difficult to 1 . the house as I had lost the address given to me by a friend of mine. I found it at last and rang the bell. An old man opened the door and he looked 2............ at me. He was wearing an old $3 . . . . . . .$. which was a proof of his $4 \ldots \ldots \ldots . .$. He asked me to come in with the air of a man full of suspicion. I stepped inside the 5.........which was small dark and dirty. When I told him that the $6 \ldots . . .$. Was from his son, he became quite friendly with me.

\section{Helping with grammar}

\section{Task 1:}

Read the following table and make three meaningful sentences from the table using the structure 'too...............to'

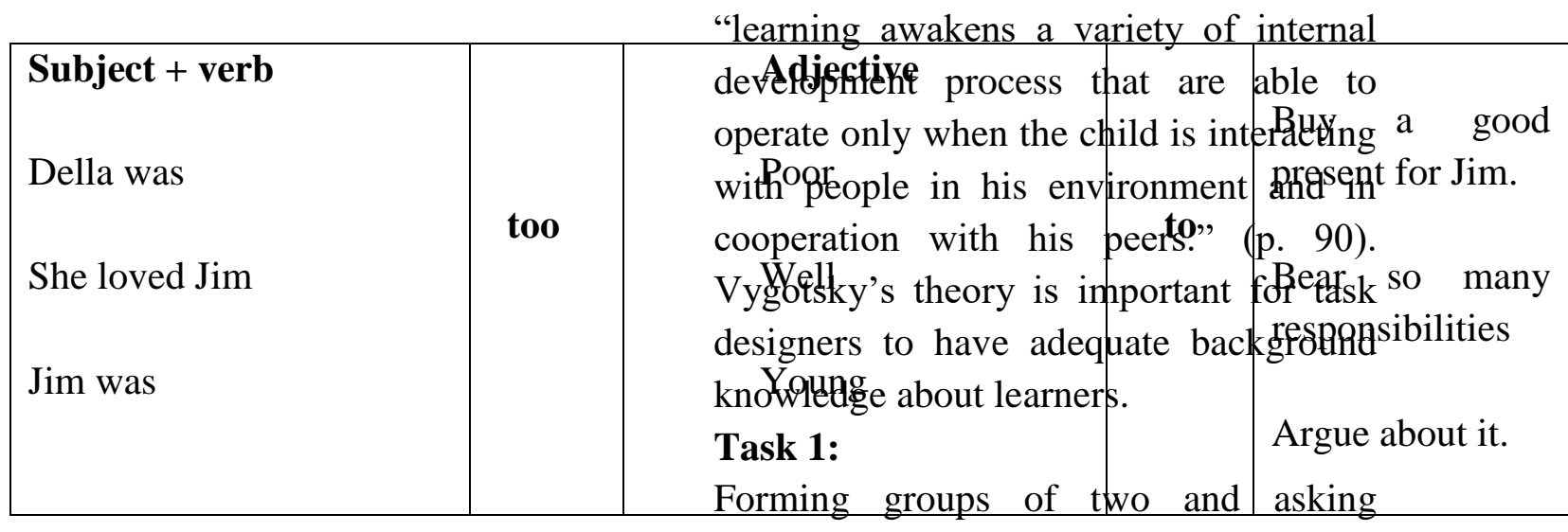
students to role play for Jim and Della

Task 2: They're too nice to use just at present. Jim was sensible enough to understand Della's Basing on the above examples, do the following sentences as directed. a. It is very hot outside. None can go out. (too)

b. The house is very expensive. We cannot afford it. (too)

e. The city is reasonably safe. We can move around at night (enough)

\section{Task 3:}

I cut it off. The pattern in the sentence is verb + it + adverbial particle. Make meaningful sentences from the table below.

\begin{tabular}{|l|l|c|}
\hline $\begin{array}{l}\text { Subject+ } \\
\text { verb }\end{array}$ & object & $\begin{array}{l}\text { Adverbial } \\
\text { particle }\end{array}$ \\
\hline He knocked & & down \\
\hline I kicked it & it & up \\
\hline Please put & & off \\
\hline
\end{tabular}

\section{Helping with oral communication}

What Vygotsky (1978) has to say about the Zone of Proximal Development is: "learning awakens a variety of internal devedjestivent process that are able to operate only when the child is interatung a good withoprople in his environment argsent for Jim. cooperation with his peers." (p. 90). Vygbtsky's theory is important forearsk so many designers to have adequate backgfrgm knowledge about learners.

Task 1:

Argue about it. 
VS Publications

Alford Council of International English \& Literature Journal(ACIELJ)

Impact Factor:4.401(SJIF)An International Peer-Reviewed English Journal

www.acielj.com

Vol-3,Issue-2 ,2020

ISSN:2581-6500

Task 2: Engaging students in a debate on whether Jim and Della behaved sensibly by parting with their most valuable possessions.

\section{Helping with writing}

\section{Task: 1}

Write a summary of the story by framing sentences in the gaps in the table.

In this story the problem starts when

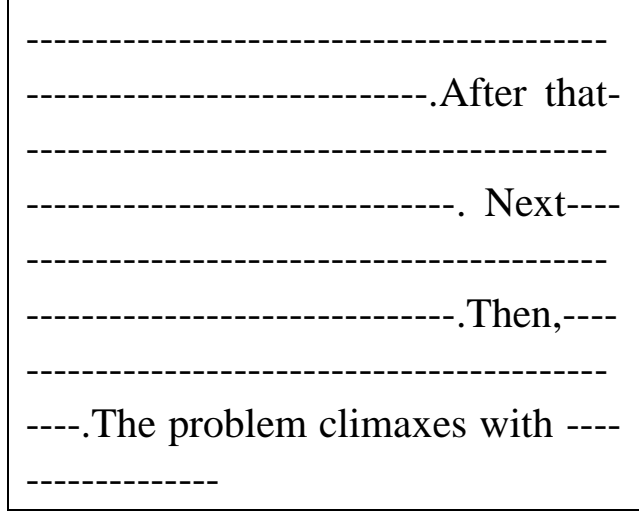

\section{Task: 2}

-Write five statements about Jim. Three should be true and two should be false.

- "Jim stopped inside the door, as immovable as a setter at the scent of quail."- How would you explain this reaction of Jim? Write five sentences.

\section{Post-Reading Activities}

The post-reading activities help students (Lazar)

--To make interpretations of the text

-- To understand the narrative point of view

-- Practice the language skills
-- Help learners express their personal viewpoints and experiences

The following activities can be done to increase better understanding of the story in the form of writing and then discussion.

- What lessons of human values do you draw from your reading of the story?

- Do you agree with the author's view as expressed in the concluding sentence, "Of all who give and receive gifts, such as they are the wisest. Everywhere they are wisest. They are the magi."?

- In the story strong family relationship is reflected. Do you believe that now -a-days families have such feelings? Generally how have relationships changed? In what ways?

- If you were to write a similar story, how would you develop it? Would you give a similar or different ending?

\section{Conclusion}

If this model can be applied at the higher secondary level and more importantly, at first year undergrad levels in English Departments in Bangladesh, it will not will not only help learners in appreciating literature but also encourage meaningful language learning. Until now in Bangladesh language learning is mostly a matter of silent and passive individual activity. 'Integrated model' will engage students to take part actively in language learning through classroom interaction. For this model to be successful there are two hurdles: one at policy level and another at pedagogy level. At policy level 
VS Publications

Alford Council of International English \& Literature Journal(ACIELJ)

Impact Factor:4.401(SJIF)An International Peer-Reviewed English Journal

www.acielj.com

Vol-3,Issue-2, 2020

ISSN:2581-6500

English Departments at colleges and universities have to accept this model and at pedagogy level teachers must be made aware that language and literature are interdependent and complement each other. So they have to be integrated.

\section{References}

[1]Brumfit, C. J. \& Carter, R. (1996). Literature and Language Teaching. Oxford: OUP.

[2]Carter, Ronald \& Michael N. Long. (1991). Teachig Literature. Harlow: Longman

[3]Cruz. J. H. R. (2010). The role of literature and culture in English language teaching.. Linguistica Aplicada, 2010, p.4. Accessed on March $\quad 15, \quad 2020$ http://relinguistica.azc.uam.mx/no0 07/no07_art09.htm

[4]Duff, Alan \& Maley, Alan. (1990). Literature. Oxford: OUP.

[5]Fenner, Anne-Britt. (2000). Cultural awareness In Approaches to Materials Design in European Textbooks: Implementing Principles of Authenticity, Learner Autonomy, Cultural Awareness, edited by Anne-Britt Fenner and David Newby, 142-150. Strasbourgh: European Centre for Modern Languages.

[6]Ghosn, Irma K. (2002). Four good reasons to use literature in primary school ELT. ELT Journal 56(2): 172-177.

[7]Gilory, Marie, and Parkinson, Brian. (1996). Teaching literature in a foreign language. Language

Teaching 29 (4): 213-225.
[8]Healy, Sandra. (2010).

Literature in the EFL classroom:from theory to practice. P. 178-191.Accessed March 14, 2020 http://ksurep.kyotosu.ac.jp/dspace/bistream/10965/34 7/1/AHSUSK HS 42 178.pdf [9]Khatib, M., Derakhshan, A., \& Rezaei, S. (2011). Why and why not literature: A task-based approach to teaching literature. International Journal of English Linguistics, 1, 213-218.

[10]Kramsch, Claire. (1998). Context and Culture in Language Teaching. Oxford: OUP.

[11]Lazar, Gillian. (1993). Literature and Language Teaching: A Guide for Teachers and Trainers. Cambridge: Cambridge University Press.---,(1999).

A Window on Literature. Cambridge: CUP

[13]Lima, C. (2010). Selecting literary texts for language learning. Accessed April 10, 2020 at www.nepjol.info?index.php/NELT A

[14]Maley, A. (1989). Down from the pedestal: literature as resource. In C. Brumfit \& R. Carter (Eds.) Literature and the Learner: Methodological Approaches, ELT Documents. P. 10-23.

[15]Maley, A. (1989). The Inward Ear: Poetry in the Language Classroom. Cambridge: CUP

[16]Povey, John.(1979). The teaching of literature in advanced ESL classes. In Teaching English as a Second or Foreign Language, edited by Marianne Celce-Murcia 
VS Publications

Alford Council of International English \& Literature Journal(ACIELJ)

Impact Factor:4.401(SJIF)An International Peer-Reviewed English Journal

www.acielj.com

ISSN:2581-6500

and Lois McIntosh, 162-186.

Rowley, MA: Newbury House.

[17]Richards, Jack C. (2005).

Materials development and

research- making the connection.

Accessed March 27,

.www.professorjackrichards.com

/.../materials- development-

making-conn.

[18]Savvidou, Christine. (2004).

An integrated approach to teaching literature in the EFL classroom.

The Internet TESL Journal X(12).

Accessed March 30, 2020.

http://iteslj.org/.

[19]Tatsuki, Donna Hurst. (2015).

Storytelling: repositioning literary

texts in language teaching: the state

of the art. Kobe City University of
Foreign Studies Annals of Foreign

Studies vol. 90

[20]Violetta-Irene, Koutsompou. (2015). The use of literature in language classroom: methods and aims. International Journal of Information and Education Technology, vol 5, no 1, January 2015.

[21]Vygotsky, L. (1978). Mind in Society: The Development of Higher Psychological Process. Harvard: Harvard University Press. [22]Widdowson, H.G. (1983). H.G. Widdowson on literature and ELT. Talking Shop ELT Journal 37, vol 1, p30-35

[23]Widdowson, H.G. (1975). Stylistics and the teaching of literature. London: Longman 